\title{
First record of Paratanaisia bragai (Digenea: Eucotylidae) in blue and gold macaw (Ara ararauna)
}

\author{
Primeiro registro de Paratanaisia bragai (Digenea: Eucotylidae) em arara Canindé (Ara ararauna) \\ Tarcísio Macedo Silva ${ }^{1}$; Leonardo Fabrício Pavan²; Priscylla Tatiana Chalfum Guimarães-Okamoto ${ }^{3}$; \\ Elisane Lenita Milbradt ${ }^{1}$; Raphael Lúcio Andreatti Filho ${ }^{1}$; Reinaldo José da Silva ${ }^{4}$; Adriano Sakai Okamoto ${ }^{1 *}$

\begin{abstract}
${ }^{1}$ Laboratório de Ornitopatologia, Departamento de Clínica Veterinária, Faculdade de Medicina Veterinária e Zootecnia, Universidade Estadual Paulista - UNESP, Botucatu, SP, Brasil Universidade Estadual Paulista - UNESP, Botucatu, SP, Brasil

${ }^{3}$ Clínica de Pequenos Animais, Departamento de Clínica Veterinária, Faculdade de Medicina Veterinária e Zootecnia, Universidade Estadual Paulista - UNESP, Botucatu, SP, Brasil

${ }^{4}$ Laboratório de Parasitologia, Departamento de Parasitologia, Instituto de Biociência, Universidade Estadual Paulista - UNESP, Botucatu, SP, Brasil
\end{abstract} \\ ${ }^{2}$ Serviço de Patologia Veterinária, Departamento de Clínica Veterinária, Faculdade de Medicina Veterinária e Zootecnia,
}

Received March 31, 2015

Accepted April 20, 2015

\begin{abstract}
The aim of this study was to provide the first report on a new host for the digenean Paratanaisia bragai in the caninde macaw Ara ararauna along with the pathological aspects of the infection in the new host. The microscopic findings revealed the presence of granulomatous interstitial nephritis. This study contributes towards knowledge of parasitism by $P$. bragai in $A$. ararauna, and emphasizes the need to use best practices in wildlife conservation parks.
\end{abstract}

Keywords: Parasite, birds, histopathology, wildlife, macaw.

\section{Resumo}

O objetivo deste estudo foi relatar, pela primeira vez, a arara canindé Ara ararauna como um novo hospedeiro para o digenético Paratanaisia bragai, bem como relatar aspectos patológicos relacionados à infecçáo no novo hospedeiro. Os achados microscópicos revelaram nefrite intersticial granulomatosa. Este estudo contribui para o conhecimento do parasitismo por $P$. bragai em $A$. ararauna e ainda faz um alerta para a adoção de boas práticas de criação em criatórios conservacionistas da fauna silvestre.

Palavras-chave: Parasita, aves, histopatologia, fauna silvestre, arara.

Ara ararauna, the caninde macaw is a large frugivorous bird belonging to the Psittacidae family that geographically is found in tropical regions of Central America, Bolivia, Paraguay and Brazil. It inhabits floodplains containing stands of moriche (buriti) palms, swamps, savannas and wetlands. Its population is classified as having near threatened status (IUCN, 2014).

Digeneans belonging to the subfamily Eucotyloidea, family Eucolylidae, are classified into two genera: Tanaisia and Paratanaisia. Both of these affect the renal system of birds (TRAVASSOS et al., 1969). Parasitism due to Paratanaisia sp. has been reported in the following birds; pheasant, Phasianus colchicus (GOMES et al., 2005); partridge, Rhynchotus rufescens (MAPELI et al., 2003); turkey, Meleagris gallopavo (BRENER et al., 2006); cattle egret, Heron Bubulcus

*Corresponding author: Adriano Sakai Okamoto. Departamento de Clínica Veterinária, Hospital Veterinário, Faculdade de Medicina Veterinária e

Zootecnia, Universidade Estadual Paulista - UNESP, Distrito de Rubiāo Junior, s/n, CP 560, CEP 18618-970, Botucatu, SP, Brasil. e-mail: sakai@fmvz.unesp.br ibis (ABDO \& SULTAN, 2013); common waxbill, Estrilda astrild (TAVELA et al., 2014); blue-winged macaw, Propyrrhura maracana; parakeet, Pyrrhura leucotis (LUPPI et al., 2007); guinea-fowl, Numida meleagris (MENEZES et al., 2001); spot-winged wood quail (uru), Odontophorus capueira; common toucan, Rhamphastos toco; tataupa tinamou, Crypturellus tataupa (TRAVASSOS et al., 1969); domestic hen, Gallus gallus domesticus (COSTA et al., 1975); red bird-of-paradise, Paradisaea rubra (UNWIN et al., 2013); and, especially, in Columbiformes: Columbina talpacoti, Columbia livia, Columba mayeri, Zenaida graysoni, Stigmatopelia senegalensis, Chalcophaps indica and Gallicolumba crinigera (BUNBURY et al., 2008; UNWIN et al., 2013).

Yet Paratanaisia bragai has not been reported in blue-and-gold macaws; Ara ararauna, only P. robusta (LUPPI et al., 2007).

Although it has been reported that Paratanaisia affects the avian hosts, the degree of parasitism and the pathological impairment relating to infection are still a matter of debate. Little consensus has been reached regarding information about these aspects of 
the species that have been reported to be hosts for this genus (UNWIN et al., 2013). So far, it is known that this parasite is present in the renal system of some of the species involved, which leads to kidney volume increase, atrophy, asymmetry, cysts, changes to parenchymal coloration, distortion or dilatation, or even absence of changes (LUPPI et al., 2007). The microscopic alterations found in some hosts range from little inflammatory reaction (MAPELI et al., 2003) to dilation of medullary collector ducts (PINTO et al., 2004), necrosis, fibrosis, poor hyperplasia, mononuclear infiltration accentuated with intraluminal eosinophilic hyaline tubular degeneration, hemosiderin pigmentation within the tubular lining epithelium, hemorrhage, granulomatous nephritis and chronic granulomatous interstitial nephritis (ABDO \& SULTAN, 2013; LUPPI et al., 2007; UNWIN et al., 2013).

In this first record of Paratanaisia bragai in caninde macaws (A. ararauna), we describe pathological data found in two cases of infection in this bird species.

Five specimens of $A$. ararauna from a conservation hatchery located in the rural municipality of Itatinga (23 $\left.06^{\prime} 06^{\prime \prime} \mathrm{S}, 48^{\circ} 36^{\prime} 57^{\prime \prime} \mathrm{W}\right)$, state of São Paulo, Brazil, were necropsied on March 13, 2014. During the necropsies, no macroscopic alterations were observed, except for paleness in the kidneys of two birds. Fragments from several organs were collected, fixed in $10 \%$ formalin, processed and embedded in paraffin. Histological sections of $4 \mu \mathrm{m}$ thickness were cut and stained using hematoxylin and eosin. Among the samples from these five animals that were evaluated microscopically, the kidney fragment samples from the two birds that presented macroscopic alterations revealed the presence of flattened, elongated structures, wrapped in a refringent capsule that contained basophilic structures similar to those of digenean trematodes. These findings were similar to those illustrated by Fletcher et al. (2008).

Subsequently, the digeneans were recovered from formalin and identified as $P$. bragai. The kidney samples that had previously been placed in formalin were gently sliced to search for parasites. Nearly 20 wax-embedded parasites, which were stained with acetic carmine and subsequently cleared and stained with creosote, were recovered. Morphological analysis on the features of the genus Paratanaisia showed the following: elongated flattened body; tegument with spines; subterminal oral sucker; small acetabulum; intestinal caecum fused near the posterior end; post-bifurcal and pre-ovarian genital pore; pre-equatorial and post-ovarian testicles, largely intercaecal with lobed edge; pre-testes ovary of irregular outline; extracaecal vitellaria extending from bifurcal zone to the posterior region of the body; and intercaecal uterus, from the bifurcal zone to the posterior region. The species $P$. bragai was confirmed through morphometric analysis on the body $(2.67 \pm 0.8$ by $0.52 \pm 0.15)$, which differed this species from Paratanaisia robusta and Paratanaisia confusa (THATCHER, 1993; VICENTE et al., 1995).

The histological aspects of the lesions were similar in the two birds parasitized by $P$. bragai and the following were seen: marked vascular congestion with hemorrhagic focus, numerous hemosiderin pigments, moderate vacuolar degeneration of renal tubules (Figure 1) and parasitic organization in the renal interstitium (Figure 2), thus resulting in a moderate mononuclear inflammatory cell infiltration, associated with deposition of fibrous

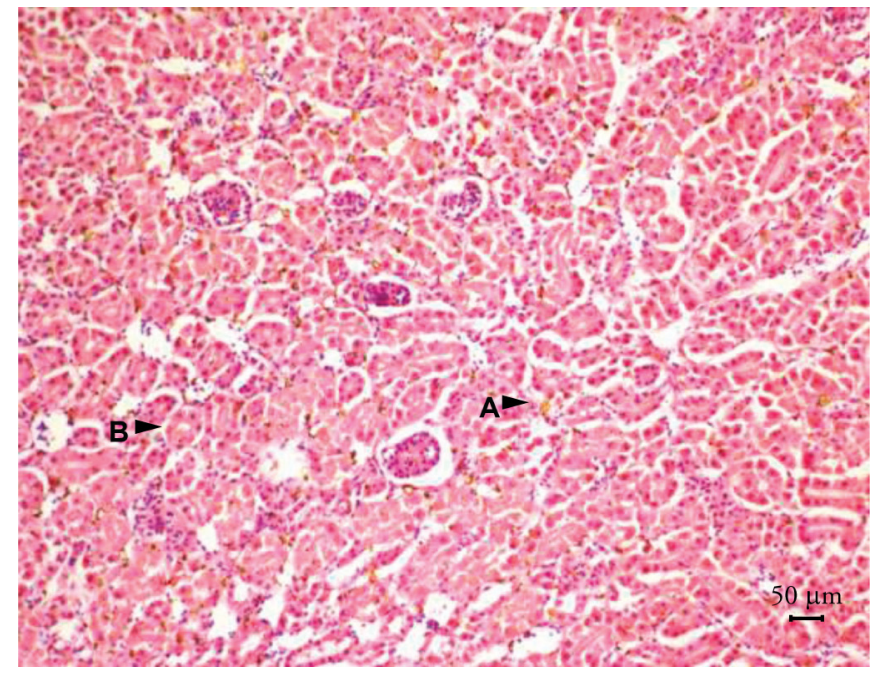

Figure 1. Histological section through kidney of Ara ararauna showing deposition of hemosiderin (A) and vacuolar tubular degeneration (B) $(\mathrm{HE})$.

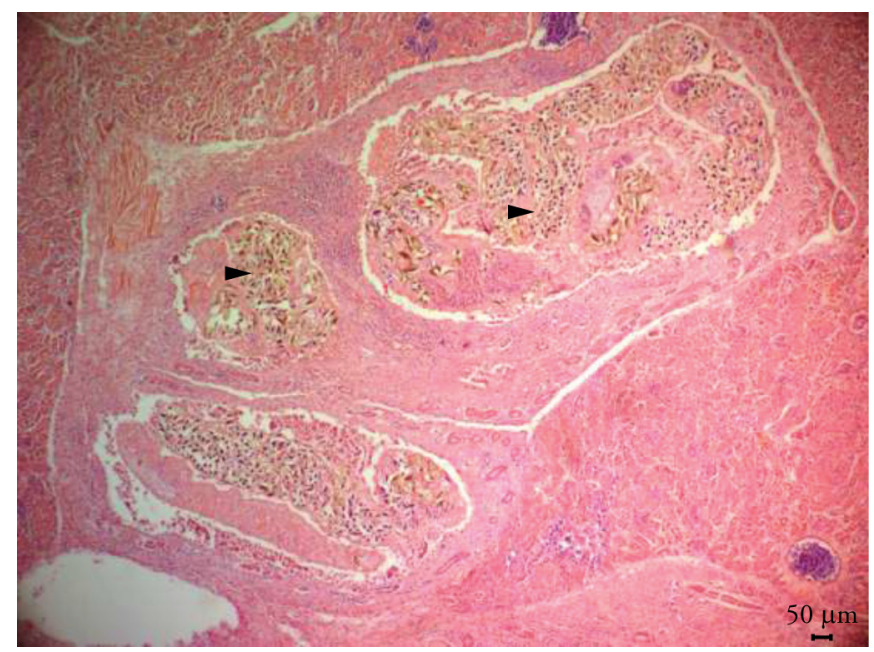

Figure 2. Histological section through kidney of Ara ararauna showing parasitic organization in the renal interstitium (HE).

tissue. The lesions worsen in a manner directly proportional to the size of the parasite (Figure 3). The diagnosis was established as "granulomatous interstitial nephritis" caused by P. bragai (Figure 4).

Trematodiasis causing chronic granulomatous nephritis has been described only once by Luppi et al. (2007). These were fatal infections, resulting in chronic kidney disease and mortality among birds of the family Psittacidae raised in captivity. In that study Luppi et al. (2007) reported infections due to the species Paratanaisia robusta in Ara ararauna and P. bragai in Propyrrhura maracana and Pyrrhura leucotis. However, we did not find any reports on parasitism by $P$. bragai in Ara ararauna, and thus this present report provides the first record of parasitism in this bird species, along with the first report of chronic infection by $P$. bragai in this species.

Unwin et al. (2013) described new hosts for P. bragai, along with the molecular and microscopic aspects of parasitism, with occurrences of granulomatous inflammatory reactions. 


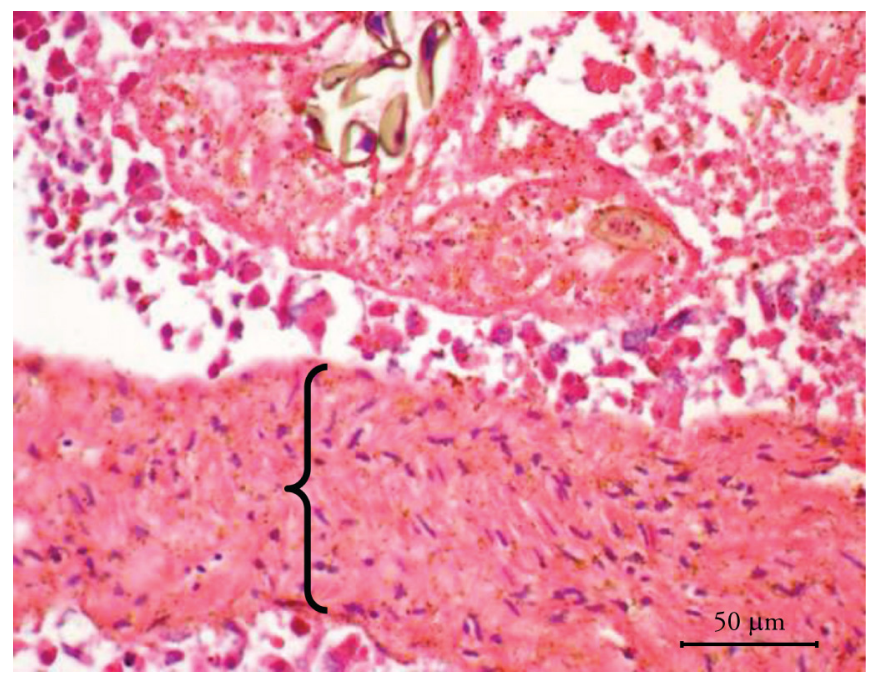

Figure 3. Histological section through kidney of Ara ararauna showing deposition of fibrous tissue due to parasitism by P. bragai (HE).

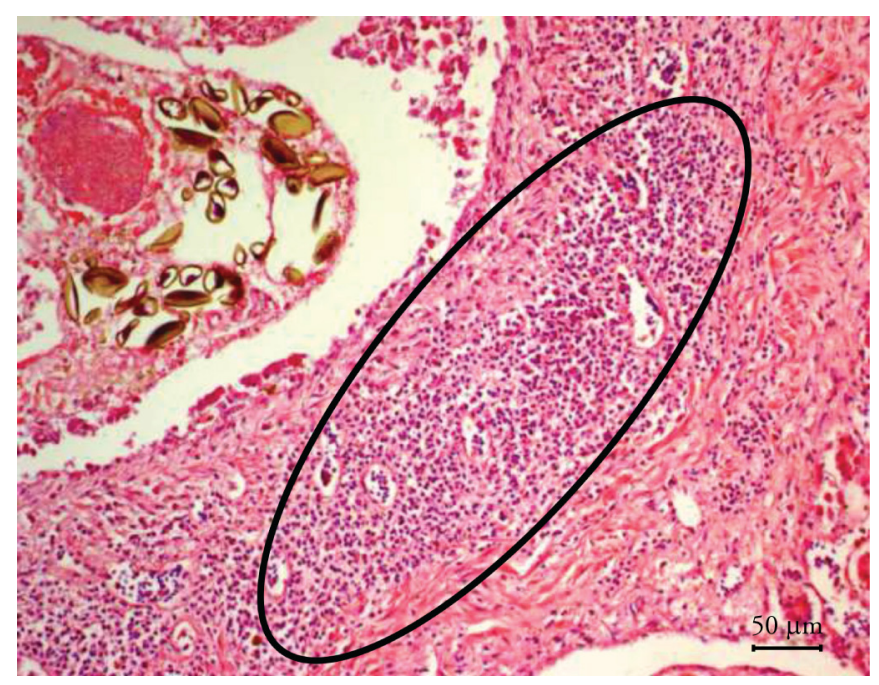

Figure 4. Histological section through kidney of Ara ararauna showing chronic nephritis with mononuclear cell infiltrate associated with infection by $P$. bragai (HE).

The microscopic results presented here are similar to those of Unwin et al. (2013). Other data obtained by Abdo \& Sultan (2013) from Bubulcus ibis showed that parasitism caused renal tubular hyperplasia. However, no such findings were observed in the bird species studied here.

The degree of severity of renal injury observed microscopically varied according to the size of the parasite, such that there was lower deposition of fibrous connective tissue in relation to the smaller specimens. This was in agreement with the injuries described by Gomes et al. (2005) and Unwin et al. (2013).

Systematic and pathological studies on mortality have an important role with regard to obtaining information on the behavior of new illnesses, especially among wild species that are threatened with or vulnerable to extinction (BUNBURY et al., 2008). Information on this new host species for a parasite (P. bragai) that has been described as a chronic and fatal condition (LUPPI et al., 2007;
UNWIN et al., 2013) for this species, which is experiencing population decline in natural settings (IUCN, 2014), will play an important role in improving the management of breeding programs.

We suggest that best practices need to be sought in breeding programs, especially in wildlife conservation parks. Some molluscs have an important role in the production of metacercariae, in the cycle of avian infection due to P. bragai (BRANDOLINI \& AMATO, 2006). Therefore, gastropod eradication in the parks becomes important. Columbiformes are known to be the main hosts for P. bragai (PINTO et al., 2004; UNWIN et al., 2013) because they are synanthropic and lead to important diseases (ROCHA-E-SILVA et al., 2014). Special attention is needed in drawing up strategies for avoiding accidental risks relating to introduction of trematodes and diseases caused by them within wildlife parks, so as to keep hatcheries safe.

The pathological findings regarding the lesions, as observed in this study; demonstrate a situation of chronic impairment. These findings add to what has already been described a few times in other species. They also serve as a parameter and as a source of new information regarding new host infection, and provide a warning that best management practices for bird breeding programs within wildlife conservation parks need to be sought.

\section{References}

Abdo W, Sultan K. Histopathological findings of the kidney Trematoda Paratanaisia spp. (Digenea: Eucotylidae) in cattle egret (Bubulcus ibis). Rev Bras Parasitol Vet 2013; 22(2): 312-313. http://dx.doi.org/10.1590/ S1984-29612013000200050. PMid:23856732.

Brandolini SVPB, Amato SB. Desenvolvimento larval de Paratanaisia bragai (Santos) (Digenea, Eucotylidae) sob condiçóes experimentais. Rev Bras Zool 2006; 23(4): 1097-1100. http://dx.doi.org/10.1590/S010181752006000400017 .

Brener B, Tortelly R, Menezes RC, Muniz-Pereira LC, Pinto RM. Prevalence and pathology of the nematode Heterakis gallinarum, the trematode Paratanaisia bragai, and the protozoan Histomonas meleagridis in the turkey, Meleagris gallopavo. Mem Inst Oswaldo Cruz 2006; 101(6): 677-681. http://dx.doi.org/10.1590/S0074-02762006000600017. PMid:17072483.

Bunbury N, Stidworthy MF, Greenwood AG, Jones CG, Sawmy S, Cole RE, et al. Causes of mortality in free-living Mauritian pink pigeons Columba mayeri, 2002-2006. Endanger Species Res 2008; 9(3): 213-220. http://dx.doi.org/10.3354/esr00088.

Costa JO, Guimarães MP, Grisi L, Barros GC. Helmintos parasitos de Gallus gallus domesticus (L.) no litoral sul do Espírito Santo. Arq Esc Vet UFMG 1975; 27(1): 45-46.

Fletcher OJ, Abdul-Aziz T, Barnes HJ. Urinary system. In: Fletcher O. Avian histopathology. 3rd ed. Jacksonville: American Association of Avian Pathologists; 2008. p. 238-259.

Gomes DC, Menezes RC, Tortelly R, Pinto RM. Pathology and first occurrence of the kidney trematode Paratanaisia bragai (Santos, 1934) Freitas, 1959 (Digenea: Eucotylidae) in Phasianus colchicus L., 1758, from Brazil. Mem Inst Oswaldo Cruz 2005; 100(3): 285-288. http:// dx.doi.org/10.1590/S0074-02762005000300013. PMid:16113870. 
International Union for Conservation of Nature and Natural Resources - IUCN. 2014 [cited 2014 Out 07]. Available from: http://www. iucnredlist.org

Luppi MM, Melo AL, Motta ROC, Malta MCC, Gardiner CH, Santos RL. Granulomatous nephritis in psittacines associated with parasitism by the trematode Paratanaisia spp. Vet Parasitol 2007; 146(3-4): 363366. http://dx.doi.org/10.1016/j.vetpar.2007.03.011. PMid:17418949.

Mapeli EB, Nascimento AA, Szabó MPJ, Tebaldi JH. Infecçôes naturais por helmintos em perdizes (Rhynchotus rufescens Temminck, 1815) de cativeiro, no Município de Jaboticabal, Estado de São Paulo. Arq Inst Biol (Sao Paulo) 2003; 70(4): 415-418.

Menezes RC, Mattos DG Jr, Tortelly R, Muniz-Pereira LC, Pinto RM, Gomes DC. Trematodes of free range reared guinea fowls (Numida meleagris Linnaeus, 1758) in the state of Rio de Janeiro, Brazil: morphology and pathology. Avian Pathol 2001; 30(3): 209-214. http://dx.doi. org/10.1080/03079450124448. PMid:19184902.

Pinto RM, Menezes RC, Tortelly R. Systematic and pathologic study of Paratanaisia bragai (Santos, 1934) Freitas, 1959 (Digenea, Eucotylidae) infestation in ruddy ground dove Columbina talpacoti (Temminck, 1811). Arq Bras Med Vet Zootec 2004; 56(4): 472-479. http://dx.doi. org/10.1590/S0102-09352004000400008.
Rocha-e-Silva RC, Maciel WC, Teixeira RSC, Salles RPR. O pombo (Columba livia) como agente carreador de Salmonella spp. e as implicações em saúde pública. Arq Inst Biol 2014; 81(2): 189-194. http://dx.doi. org/10.1590/1808-1657000702012.

Tavela AO, Carretta Junior M, Oliveira AR, Carneiro FT, Silva VHD, Braga FR, et al. Parasitism by Paratanaisia bragai (Digenea, Eucotylidae) in commom waxbill (Estrilda astrild). Arq Bras Med Vet Zootec 2014; 66(4): 1276-1280. http://dx.doi.org/10.1590/1678-7136.

Thatcher EV. Trematódeos neotropicais. Manaus: INPA; 1993.

Travassos L, Freitas JFT, Kohn A. Trematódeos do Brasil. Mem Inst Oswaldo Cruz 1969; 67(1): 1-886. PMid:5397756.

Unwin S, Chantrey J, Chatterton J, Aldhoun JA, Littlewood DTJ. Renal trematode infection due to Paratanaisia bragai in zoo housed Columbiformes and a red bird-of-paradise (Paradisaea rubra). Int J Parasitol Parasites Wildl 2013; 2: 32-41. http://dx.doi.org/10.1016/j. ijppaw.2012.11.001. PMid:24533313.

Vicente JJ, Rodrigues HO, Gomes DC, Pinto RM. Nematóides do Brasil. Parte IV: Nematóides de aves. Rev Bras Zool 1995; 12(S1): 1-273. http:// dx.doi.org/10.1590/S0101-81751995000500001. 